PRZEGLĄD RUSYCYSTYCZNY 2020, nr 3(171)

DOI $10.31261 /$ pr. 7883

SVETLANA PAVLENKO

Uniwersytet Gdański

(D ORCID: http://orcid.org/oooo-ooo2-7443-2856

\title{
PRZESTRZEŃ, WOJNA I PAMIĘĆ W DOKUMENTALNO- -ARTYSTYCZNEJ PROZIE SWIETŁANY ALEKSIJEWICZ
}

\author{
SPACE, WAR AND MEMORY \\ IN THE FICTION AND DOCUMENTARY PROSE OF SVETLANA ALEXIEVICH
}

The analysis of literature evidences of the Great Patriotic War is closely connected with the consideration of the category of space. The war scenery represents not only the model of geographical space but has the symbolic status acting as the place of memory. The aim of the present article is the research of memory sceneries presented in the first two books of the Nobel prize winner Svetlana Alexievich. In the works of Belarusian writer the space, war and memory act in difeferent configurations, creating complicated and multi-level system where the number of repeating motives and images can be found. The peculiarities of women and children memory functioning determine the ways of constructing space and identity of a person in it. The article analyzes various types of the space: the own and the others one, the space of initiation, the taboo spaces, acoustic space, heterotopias, etc. composing the world of the Great Patriotic war seen by the eyes of Alexievich characters.

Keywords: Svetlana Alexievich, the Great Patriotic War, space, memory places, fiction and documentary literature

Kultura w perspektywie semiotycznej - jak twierdzi Jurij Łotman - stanowi pamięć zbiorową. Przestrzeń kultury wedle badacza to „пространство некоторой общей памяти, [...] в пределах которого некоторые общие тексты могут сохраняться и быть актуализированы". Pamięc kultury nie posiada układu homogenicznego, bowiem jej struktura składa się z prywatnych „dialektów pamięci” ${ }^{2}$. Procesy indywidualizacji pamięci najbardziej uwidacznia-

1 Ю.М. Лотман, Память в культурологическом освещении, http://www. philology.ru/literature1/lotman-92f.htm (15.05.2019).

2 Tamże. 
ją się w małych narracjach formułowanych przez poszczególne osoby, które poprzez swoją obecność w przestrzeni kultury burzą panujące w społeczeństwie metanarracje. Każda kultura wyznacza granice pamięci, inaczej mówiąc, ma wpływ na to, co podlega upamiętnianiu, a co może ulec zapomnieniu. Jednak z biegiem czasu zmienia się system kodów kulturowych, a więc i sam paradygmat pamięci-zapomnienia, czego przykładem jest metanarracja o drugiej wojnie światowej, przeciwko której zostały wymierzone mikronarracje zawarte przede wszystkim w literaturze pięknej oraz literaturze faktu. Elżbieta Rybicka zauważa:

Domeną literatury jest przecież pamięć jednostkowa, migawkowa, zawodna, a nie zobiektywizowana wizja historii. Świadczy o tym chociażby kryzys powieści historycznej wypieranej przez szeroko rozumianą literaturę świadectwa³ ${ }^{3}$.

Doświadczenie wojny utrwalone w pamięci jej uczestników i świadków jest ściśle związane z kategorią przestrzeni. Katarzyna Szalewska podkreśla, że

pisanie o literackich świadectwach egzystencji musi stać się namysłem również nad przestrzenią, nie tylko w sensie fenomenologii ruin czy historiograficznych rekonstrukcji topografii działań militarnych, lecz także spacjalnych praktyk właściwych dla semiotyki codzienności miejskiej. Krajobraz w tej perspektywie staje się jednocześnie celem walki (jako terytorium zajmowane, okupowane, odzyskiwane), jej areną (jako pole bitewne, teren, na którym toczy się walka) oraz wartością symboliczną [...]

Celem niniejszego artykułu jest próba analizy wojennych krajobrazów pamięci (memoryscape) na przykładzie utworów Swietłany Aleksijewicz Wojna nie ma $w$ sobie nic z kobiety (У войны не женское лицо, 1985) oraz Ostatni świadkowie (Последние свидетели, 1985)

3 E. Rybicka, Miejsce, pamięć, literatura (w perspektywie geopoetyki), „Teksty Drugie" 2008, nr 1-2, s. 22.

4 K. Szalewska, Urbanalia. Miasto i jego teksty, Słowo/obraz terytoria, Gdańsk 2017, s. 127.

5 Zagadnienie pamięci i mechanizmów jej funkcjonowania w twórczości Aleksijewicz zostało poruszone m. in. W pracach: B. Darska, Ludzie radzieccy. $O$ tożsamości, nierównej walce $z$ czasem, pamięci $i$ zapomnieniu $w$ reportażach Swiettany Aleksijewicz, w: B. Morzyńska-Wrzosek, M. Kurkiewicz, I. Szczukowski (red.), Tożsamość. Kultura. Nowoczesność, t. 2, Czas. Pamięć, Wydawnictwo Uniwersytetu Kazimierza Wielkiego, Bydgoszcz 2017, s. 329-344; E. Bielska, Niewrażliwe państwo, wrażliwa literatura. Prace Swietłany Aleksijewicz jako 
Książka debiutancka Wojna nie ma $w$ sobie nic z kobiety rozpoczyna się od uruchomienia mechanizmu pamięci samej autorki, która określa wojnę jako jedyny znany jej świat funkcjonujący według własnych zasad. Stwierdzenie, że wojna stanowi odrębny model świata, powtórzy się również w Cynkowych chłopcach (Цинковые мальчикu, 1989): „Война - мир, а не событие... Все здесь другое: и пейзаж, и человек, и слова. Запоминается театральная часть войны: разворачивается танк, звучат команды...”. Natomiast wspomnienia zawarte w jej książkach reprezentują zakulisowe oblicze wojny, która ten świat rekonstruuje, a zatem warstwa po warstwie odsłania. W przeciwieństwie do Cynkowych chłopców w pierwszej książce mamy do czynienia ze szczególną relacją autorki z bohaterkami postpamięcią? Aleksijewicz na początku zaznacza, że jej dzieciństwo i młodość przebiegały $\mathrm{w}$ atmosferze traumatycznych wspomnień członków rodziny.

Głosy mówiące o wojnie, które towarzyszyły autorce od dzieciństwa, należały do kobiet, a świat wojny wyrastał z kobiecych narracji: „Деревня моего детства после войны была женская. Бабья. Мужских голосов не помню" i kobiecością, zachodziła konfrontacja dwóch form pamięci - zbiorowej (wielkiej narracji tworzonej przez mężczyzn i przez nich utrwalonej) i indywidualnej (reprezentowanej przeważnie przez kobiety, których „małe historie” zostały z pamięci zbiorowej wykluczone, uznane za niewarte zapisu bądź przemilczane). Kobiecy świat wojny posiada inny wymiar, którego podstawę stanowią uczucia9 ${ }^{9}$. Jest on zwrócony

egzemplifikacje traumy (nie)wypowiedzianej, „Kultura Współczesna” 2018, nr 4, s. 70-80; R. Zawadzki, Violence and Emotion: Feminine Perspectives in the Works of Svetlana Alexievich, Luisa Valenzuela, Lydia Chukovskaya, and Claudia Hernández, Chapel Hill 2018, s. 10-14, https://cdr.lib.unc.edu/concern/ honors_theses/st74cv233 (24.12.2019) i in. W centrum uwagi badaczy znajduje się zwłaszcza relacja pamięć-tożsamość, natomiast związek pamięci i przestrzeni w tekstach Aleksijewicz nadal pozostaje obszarem zmarginalizowanym.

6 С. А. Алексиевич, Цинковые мальчики, Время, Москва 2017, s. 23.

7 Zob. M. Hirsch, The Generation of Postmemory, „Poetics Today” 2008, nr 29, s. 103-128, https://urokiistorii.ru/sites/all/files/hirsch_generation_of_postmemory.pdf (15.05.2019).

8 С. Алексиевич, У войны не женское лицо, Время, Москва 2007, s. 7.

9 Temat doświadczenia wojennego kobiet w prozie Aleksijewicz niejednokrotnie stawał się przedmiotem analiz. Wymienię niektóre z prac poświęcone temu zagadnieniu: A. Горшенин, O войне - невоевавшие, „Сибирские огни” 1985, nr 5, s. 156-158; S. Kępa, Dlaczego wojna nie ma w sobie nic z kobiety?...Żotnierki II wojny światowej $w$ reportażach Swiettany Aleksijewicz. Mapa mentalna, 
ku sobie, wypełniony zapachami, barwami i na pierwszy rzut oka nieznaczącymi drobiazgami.

We wspomnieniach bohaterek pojawiają się zarówno rodzime krajobrazy zniekształcone lub zniszczone przez wojnę (lejtmotywem książki jest spalona wieś), jak i przestrzenie kraju okupanta. Opozycja „swój-obcy” oraz perspektywa oglądu świata stają się niezwykle ważne w kreowaniu świata przedstawionego. Zależy ona od zawodu wykonywanego w czasie wojny oraz od elementów tego świata stanowiących wyrazisty atrybut profesji - tę funkcję mógł pełnić stół operacyjny, ognisko w lesie, samolot (perspektywa z lotu ptaka), ziemia. W wojennym krajobrazie zaprezentowanym przez pryzmat wspomnień Apoliny Lickiewicz-Bajrak, dowódcy plutonu saperów, dostrzeżemy bez trudu, jak kraje i miasta tracą swoją tożsamość, zamieniając się w homogeniczną przestrzeń:

Прошла Чехословакию, Польшу, Венгрию, Румынию, Германию... А впечатлений в памяти осталось мало, в основном вспоминается только зрительное фотографирование рельефа местности. Валуны... Высокая трава [...] Трава старая... Лопухи выше кустов... Вспоминается еще множество ручейков и оврагов. Лесная чащоба, сплошные проволочные заграждения с подгнившими кольями, заросшие минные поля ${ }^{10}$.

Pokonywanie przez kobietę kolejnych przestrzeni pobudza jednocześnie ruch pamięci, który kieruje czytelnika coraz bardziej w głąb krajobrazu. Wysiłek pamięci przypomina mozolne kopanie w ziemi, które było wojenną codziennością bohaterki podczas służby w batalionie saperów. W przedstawionych we wspomnieniach geoobrazach dużą rolę odgrywa kod telluryczny. Związek bohaterek z ziemią ojczystą ma wymiar niemal mistyczny, nie bez znaczenia pozostaje ich wiejskie pochodzenie. $\mathrm{Z}$ ziemią powiązane są liczne rytuały - cało-

„Annales Universitatis Paedagogicae Cracoviensis. Studia Historicolitteraria” 2015, nr 15, s. 157-164; A. Zywert, Śmierć i dziewczyna. „Wojna nie ma $w$ sobie nic z kobiety" Swiettany Aleksijewicz, w: M. Grzywacz, M. Okupnik (red.), Kobiety i/a doświadczenie wojny. 1914-1945 i później, Wydawnictwo Naukowe Wydziału Nauk Społecznych UAM, Poznań 2015, s. 143-155; A. Novikau, Women, wars and militarism in Svetlana Alexievich's documentary prose, „Media, War \& Conflict” 2017, nr 10 (3), s. 314-326; A. Stępniak, Anioły czy wiedźmy? Kobiety w reportażu Swiettany Aleksijewicz Wojna nie ma $w$ sobie nic z kobiety, w: A. Stanecka, J. Dybała (red.), Wiedźmy i anioły - postrzeganie kobiet $w$ dawnej i wspótczesnej kulturze, Wydawnictwo UJK w Kielcach, Piotrków Trybunalski 2017, s. 112-122; B. Waligórska-Olejniczak, O mitach $i$ obrazach kobiecości $w$ prozie Swiettany Aleksijewicz, „Porównania” 2017, nr 1, s. 97-104 i in.

${ }^{10}$ С. Алексиевич, У войны не женское лицо..., s. 291. 
wanie, przenoszenie jej w woreczkach, żołnierze panicznie boją się, że zostaną pochowani w obcym kraju. Moc przywiązania do ziemi jest tak wielka, że Niemcy kalają ją nawet swoim dotykiem.

Wojna nie ma $w$ sobie nic $z$ kobiety zawiera w sobie liczne opisy przestrzeni, w których dokonuje się inicjacja bohaterek. Przestrzeń inicjacyjna nie posiada wyraźnie zaznaczonych granic, obejmuje wszystkie terytoria znajdujące się w obszarze wojny. Karolina Górska zauważa, że inicjacja bohaterek zachodziła podczas pierwszej walki lub w momencie zabijania wroga ${ }^{11}$, czyli w miejscach napiętnowanych strachem i cierpieniem. Locus horridus często wpisane są w sny kobiet, przestrzeń oniryczna w ich świadectwach jest nie mniej ważna niż geograficzna. Na poziomie symbolicznym inicjacja wiązała się z utratą kobiecości - założeniem męskiego stroju oraz obcinaniem warkocza $^{12}$. W przedstawianiu przestrzeni inicjacji ważną funkcję pełnią przedmioty, wskazujące na przynależność albo do świata mężczyzn, albo kobiet. Zakładanie kolczyków, przymierzanie sukienek, malowanie się, ozdabianie ziemianek kwiatami lub wstążkami - te wszystkie praktyki symboliczne mają na celu chwilowe przywrócenie zatartej tożsamości, a zarazem wskrzeszenie w pamięci przestrzeni zakazanych (chodzi przede wszystkim o przestrzenie związane z dzieciństwem, szczęściem domowego ogniska). Anna Chrołowicz wspomina, jak otrzymała podczas wojny w prezencie puderniczkę. Zapach pudru stał się katalizatorem pamięci bohaterki: „Запах пудры, эта перламутровая крышечка... Маленький ребенок... Девочка... Что-то такое домашнее, что-то из настоящей женской жизни" ${ }^{3}$. Zupełnie inne funkcje pełnią rzeczy w opisach krajobrazów niemieckich.

Żołnierki Armii Czerwonej miały przed wojną swoje życie osobiste, swój posiadający ustalony porządek świat, w obronie tego porządku walczyły zaciekle z wrogiem, który najechał ich miasta i domy. Ta motywacja wypala się w momencie, gdy wojna zaczyna się toczyć na

${ }^{11}$ Por. К. Гурска, Книга С. Алексиевич «У войны не женское лицо» как циклическое художественно-документальное явление: структура и поэтика, „Вестник РУДН. Серия: Литературоведение. Журналистика” 2018, nr 2, s. 203 , https://cyberleninka.ru/article/v/kniga-s-aleksievich-u-voyny-ne-zhenskoelitso-kak-tsiklicheskoe-hudozhestvenno-dokumentalnoe-yavlenie-struktura-ipoetika (15.05.2019).

12 Tamże, s. 204. Zob. też B. Stelingowska, „Wojna nie ma $w$ sobie nic z kobiety” - wokół reportażu Swiettany Aleksijewicz, „Doctrina” 2017, nr 14, s. 394-395, 399-400.

${ }^{13}$ С. Алексиевич, У войны не женское лицо..., s. 267. 
obcym terytorium. Obok lęku przed śmiercią z chwilą przekroczenia granic pojawiają się też inne uczucia, przede wszystkim ciekawość jak wyglądało życie Niemców? Zobaczywszy kraj bogatszy - z dużymi murowanymi domami, z obfitością niedostępnych często dla obywateli radzieckich przedmiotów codziennego użytku, bohaterkom trudno zrozumieć, dlaczego Niemcy opuścili swój wygodny i bezpieczny świat.

Niemiecka przestrzeń wydaje się żołnierkom nierealna, teatralna, baśniowa. Bełła Epsztejn wspomina: „В одном немецком поселке нас разместили на ночь в жилом замке. Много комнат, целые залы. Такие залы! В шкафах полно красивой одежды. Девочки каждая платье себе выбрала"14. Często żołnierze natrafiają na przestrzeń opuszczoną, ponieważ niemieccy cywile w panice uciekli przed radziecką armią, jest to więc przestrzeń pozbawiona życia, nosząca jedynie jego ślady. Nie można w niej zamieszkać ani zatrzymać się na dłużej, stąd także bierze się żądza zniszczenia. Obiektem agresji staje się najczęściej porcelana, dobro luksusowe, które zapada w pamięci żołnierkom przychodzącym z siermiężnej i biednej rzeczywistości lat stalinowskich.

Swietłana Aleksijewicz eksponuje także problem związku między doświadczeniem drugiej wojny światowej a kreowaniem lub odbiorem przestrzeni powojennej przez bohaterki. Należy zwrócić uwagę na opis pokoju Niny Wiśniewskiej ukazany oczami Aleksijewicz:

В большой комнате свободно, почти нет привычных домашних вещей. На полке - книги, большей частью военные мемуары, много увеличенных военных фотографий, висит на лосином рогу танкошлем, на полированном столике ряд маленьких танков с дарственными надписями [...]. Рядом со мной на диване «сидят» три куклы - в военной форме. И даже шторы и обои в комнате защитного цвета ${ }^{15}$.

Jak widać, wojenne atrybuty i pamiątki przekształcają mieszkanie kobiety w swego rodzaju muzeum pamięci. Trauma wojenna ${ }^{16}$ organizuje porządek codzienny bohaterek, wyznacza trajektorie ich ruchu po mieście, miejsca tabu, bowiem przebywanie w nich przywołuje bolesne wspomnienia:

${ }_{14}$ Tamże, s. 255.

15 Tamże, s. 124.

${ }^{16}$ Więcej na ten temat zob. E. Bielska, Niewrażliwe państwo, wrażliwa literatura..., s. 70-80; D. Lugaric Vukas, Witnessing the unspeakable: on testimony and trauma in Svetlana Alexievich's The War's Unwomanly Face and Zinky Boys, „Культура и текст” 2014, nr 3, s. 19-39. 
Летом совсем не могла оставаться в городе, старалась хоть куда-то уехать. Как только лето, мне кажется, что сейчас начнется война. Когда солнце нагревало все: деревья, дома, асфальт, - все это запах имело, все пахло для меня кровью17.

Struktura kolejnej książki Swietłany Aleksijewicz poświęconej drugiej wojnie światowej Ostatni świadkowie przypomina zasady, wedle których był skonstruowany jej pisarski debiut, z tą tylko różnicą, że głosy dziecięce nadają jej inny wydźwięk. Wiesław Theiss podkreśla, że „wiedza o wojennym cierpieniu dziecka przełamuje konwencjonalny i schematyczny obraz wojny, który na ogół skupia się na bitwach, bohaterstwie, zbrodniach, wyzwoleniu, zniewoleniu"18.

Mechanizmy funkcjonowania dziecięcej pamięci mają swoje stałe powtarzalne elementy ${ }^{19}$. Wystarczy zestawić ze sobą dwa świadectwa, które tworzą ramy utworu.

Pierwsze wspomnienie należy do Żeni Bielkiewicz, która w 1941 roku miała 6 lat. Jej pamięc - jak twierdzi bohaterka - utrwaliła wszystkie tragiczne wydarzenia tamtych lat. Wojna zastała rodzinę $\mathrm{w}$ domu, który chwilę potem opuścił ojciec dziewczynki. Następnie pamięć podsuwa inny obraz - czarne niebo, takiż samolot i martwe ciało matki leżące przy szosie. Jej śmierć wywołuje u dziecka chwilową utratę pamięci i niemotę. Opuszczony dom, wspomnienie w pośpiechu pochowanego bezpośrednio w ziemi ciała, obraz nieba i ziemi, topos drogi, motyw utraty pamięci stanowią podstawowe elementy tej narracji.

Autorką ostatniego świadectwa jest Wala Brinska, mająca w tamtym czasie 12 lat, czyli będąca dwa razy starsza, co znajduje swój wyraz również $\mathrm{w}$ formie jej narracji o wojnie. Jednak oba świadectwa wykazują pewne podobieństwa. Każde z nich rozpoczyna się od wskazania elementów cechujących dziecięcy świat (bajka, lalka), w który wkracza wojna. Najpierw dziewczynki słyszą przez sen dźwięki zbliżającej się katastrofy: „Утром проснулась от страха. От каких-то незнакомых звуков...”, „Сквозь сон слышу какой-то гул, словно

${ }_{17}$ С. Алексиевич, У войны не женское лицо..., s. 409.

${ }^{18}$ W. Theiss, Sieroctwo wojenne polskich dzieci (1939-1945). Zarys problematyki, „Przegląd Pedagogiczny” 2012, nr 1, s. 79, https://repozytorium.ukw.edu.pl/handle/item/621 (15.05.2019).

19 Zob. С. Волкова, Идейно-эстетическая функция мотива «поседелого детства» в книге С. Алексиевич «Последние свидетели», „Cuadernos de Rusística Española” 2011, nr 7, s. 236, https://revistaseug.ugr.es/index.php/cre/article/ view/103/102 (15.05.2019). 
раскаты грома, но какого-то непривычного, непрерывного" Obraz pojawienia się niemieckich bombowców utrwalił się w pamięci obu bohaterek, stając się jednym z najważniejszych elementów wojennego krajobrazu dziecięcej pamięci: „Мне потом часто снились эти самолеты. Но сон был с продолжением - все это железное небо медленно падало на меня и давило, давило, давило" 21. Rodzice Wali umarli po wojnie, właśnie ich śmierć uświadamia bohaterce, że należy ona do ostatnich świadków i uruchamia jeden z mechanizmów wychodzenia z traumy - jej wypowiedzenie.

Dziecięca pamięć ma charakter fragmentaryczny, utrwalają się w niej z reguły pojedyncze obrazki, poszczególne odbitki rzeczywistości, a w niej osobne detale:

Что я больше всего храню в памяти? Из тех дней... Как забирали отца... Он был в телогрейке, а лица его не помню, оно совершенно исчезло из моей памяти. Помню его руки... Они закрутили их веревками. Папины руки...22.

O czym zapominają dzieci wojny w pierwszej kolejności? Przede wszystkim o swoim wcześniejszym dzieciństwie, zabawkach, wymazaniu ulegają epizody przedwojennego życia, krajobrazy. Przestrzeń pamięci takiego dziecka wypełnia bowiem strach, obrazy śmierci, kolory, zapachy i dźwięki.

Pierwszorzędną rolę w kreowanej przez ostatnich świadków przestrzeni odgrywają metafory akustyczne: „Десятки незнакомых самолетов. С крестами. Они закрыли небо, закрыли солнце. Ужас! Посыпались бомбы... Беспрерывно слышались взрывы. Треск. Все происходило как во сне. Не наяву"23. Pejzaż dźwiękowy (soundlandscape) ${ }^{24}$ lączy się tu (i w innych epizodach) $\mathrm{z}$ oniryczną strategią przedstawienia rzeczywistości, w rezultacie przestrzeń fizyczna ulega dematerializacji, traci autentyczność. Audytywna przestrzeń realiów wojennych przedstawiona w Ostatnich świadkach jest wielowymiarowa, zawiera w sobie nie tylko odgłosy broni różnego typu, ale też inne dźwięki wojny. Nina Jaroszewicz

\footnotetext{
${ }^{20}$ С.А. Алексиевич, Последние свидетели. Соло для детского голоса, Время, Москва 2017, s. 6, 288.

${ }^{21}$ Tamże, s. 291.

${ }^{22}$ Tamże, s. 105.

23 Tamże, s. 8.

${ }^{24}$ Termin „pejzaż dźwiękowy” (soundlandscape) stworzył Raymond Murray Scheffer. Posługuję się nim w rozumieniu, jakim używa go na gruncie polskim Katarzyna Szalewska. Por. K. Szalewska, Urbanalia. Miasto i jego teksty..., s. 138-151.
} 
wspomina: „В Слуцке в парке повесили две партизанские семьи. Стояли большие морозы, повешенные были такие замерзшие, что когда их качало ветром, они звенели. Звенели, как замерзшие деревья в лесу...”25. Dźwiękiem-znakiem oprawców staje się w świadectwach dzieci śmiech i stukot podkutych butów. Powtarzające się motywy foniczne w różnych opisach wskazują, że dźwięk występuje w książce jako forma uprzestrzennienia pamięci zbiorowej.

Pamięć ma swoje barwy. Nikły obraz przedwojennego życia jest pełen jaskrawych kolorów i ruchu, natomiast kolory wojny w dziecięcym odbiorze są nasycone czernią i szarością (metafora wojna jako czarno-biały film). W wyniku głodu w krajobrazie naturalnym znikają wszystkie odcieni zieleni. Ania Grubina, która przeżyła blokadę Leningradu, zauważa: „В Карпинске сразу бросились в парк, мы не гуляли в парке, мы его ели. [...] С блокады я знаю всю съедобную траву, в городе люди съедали все зеленое. В парках и ботаническом саду уже с весны не оставалось листьев" ${ }^{26}$.

W porównaniu do Wojna nie ma $w$ sobie nic z kobiety w Ostatnich świadkach dominują inne perspektywy oglądu świata charakterystyczne dla dzieci, które były zmuszone stale ukrywać się przed zagrożeniem. Mamy tutaj do czynienia nie tyle z oglądaniem, ile z podglądaniem i wsłuchiwaniem się. Tak leżąca na ziemi i skryta pod płaszczem Inna Lewkiewicz przez dziurkę od guzika obserwuje biegnących ludzi i strzęp ciała ludzkiego wiszący na drzewie. Artur Kuziejew przez dziurę $\mathrm{w}$ plocie podgląda rozstrzelanie czerwonoarmistów, których nazwiska usiłuje zapamiętać. Nikołaj Bieriozka, najmłodszy świadek (rok urodzenia 1945), obserwuje przez szpary między skrzydłami drzwi swojego ojca, będącego dla niego ucieleśnieniem skutków wojny ${ }^{27}$.

W centrum uwagi bohaterów znajduje się sporo przestrzennych figur, dlatego skupię sięjedynie na kilku wybranych. Funkcje budynków w okresie wojennym okazują się płynne. Na przykład szkoły zmieniają się w szpitale, pociąg staje się domem tymczasowym, cmentarzem oraz porodówką, las (ze względu na ukrywających się w nim partyzantów) pełni funkcję schronienia. Wielka wojna ojczyźniana posiada swój słownik, w którym nie sposób znaleźć wielu podstawowych dla dziecka pojęć organizujących jego świat. Słowa „matka” i „ojciec” znikają całkowicie lub stają się słowami tabu, co się wiąże ze zjawi-

${ }^{25}$ С.А. Алексиевич, Последние свидетели. Соло для детского голоса..., s. 54.

${ }^{26}$ Tamże, s. 236.

${ }^{27}$ Zob. tamże, s. 36, 169, 282. 
skiem sieroctwa wojennego. Dom dziecka pojawiający się w licznych relacjach bohaterów jest rodzajem przestrzeni chimerycznej, heterotopią ${ }^{28}$. Reprezentacjami przestrzeni heterotopicznych w Ostatnich świadkach są również cmentarze i obozy.

Cmentarz stał się synonimem i figurą wojny, każda przestrzeń po bombardowaniu przekształcała się w „nekropolię”. Wołodia Ampiłogow, któremu udało się uciec z pociągu wiozącego dzieci do Niemiec, opisuje jedną z napotkanych po drodze wiosek następująco: „[...] стояли одни черные печи. Стелился туман... Мы шли, как по кладбищу"29. W czasie wojny cmentarz paradoksalnie kojarzył się ludziom z bezpieczeństwem, miejscem, gdzie można się ukryć przed bombami. Przecież „Зачем бомбить мертвых?”зо - pyta Giena Juszkiewicz. Natomiast Wania Titow, jakby kontynuując poprzedni wątek, zauważa: „Сожгли нашу деревню. Разбомбили деревенское кладбище. Прибежали люди туда: покойники лежали наверху... Они лежали, как будто еще раз убитые..."31. Spacjalna figura cmentarza koncentruje w sobie odmienne perspektywy historyczne, jest specyficznym zapisem historii wsi lub miasta, dlatego zbombardowany cmentarz staje się symbolem utraconej pamięci. Obozy zagłady podobnie jak zniszczone cmentarze i wojenne groby zakłócają doświadczenie przestrzeni: „В лагере не видно неба, не видно земли из-за дыма. Труба высокая, черная. День и ночь из нее валил дым..." ${ }^{2}$. Są to przykłady miejsc, które nabierają kształtu już jedynie w pamięci świadków. Zina Prichodźko dotarła na teren dawnego obozu w Azaryczach, ale nie znalazła tam po nim żadnych śladów, przykrył je zwykły przyrodniczy pejzaż: „Но что там теперь увидишь? Трава, земля... Все обыкновенное. Если что-то осталось, то только в нашей памяти...”з3.

We wspomnieniach bohaterów książki brak niemal całkowicie opisów krajobrazów miejskich. Wyjątkiem jest świadectwo Galiny Firsowej zatytułowane Piesku kochany, wybacz... Piesku kochany, wybасz... (Собака, миленькая, прости... Собака, миленькая,

${ }^{28}$ Więcej na ten temat zob. M. Kurzynoga, Heterotopia domu dziecka, czyli o miejscu bez miejsca, „Teraźniejszość - Człowiek - Edukacja” 2012, nr 4(60), s. 8795, http://terazniejszosc.dsw.edu.pl/fileadmin/user_upload/wydawnictwo/ TCE/2012_60_6.pdf (15.05.2019).

${ }^{29}$ С.А. Алексиевич, Последние свидетели. Соло для детского голоса..., s. 109.

30 Tamże, s. 9.

${ }^{31}$ Tamże, s. 44.

${ }^{32}$ Tamże, s. 133.

${ }^{33}$ Tamże, s. 172. 
прости...). Poza tym to jedna $\mathrm{z}$ niewielu relacji, w której kategoria czasowa jest nie mniej ważna niż kategoria przestrzenna: „Убивали нас голодом, убивали долго. Девятьсот дней блокады... Девятьсот... Когда один день мог показаться вечностью" 34 . Okres trwania oblężenia Leningradu oraz stwierdzenie zawarte w słowach „очень хотелось жить” powtórzone kilkakrotnie w tekście brzmią jak usprawiedliwiający refren lub formuły magiczne. Wykorzystanie mechanizmu powtórzeń wzmacnia siłę wypowiedzi oraz pozwala na głębsze zanurzenie się we własnej pamięci, odtworzenie szczegółów. W kreowaniu pejzażu miejskiego wiodącą rolę odgrywa głód, przestrzeń miasta jest tu przeżywana cieleśnie, motorycznie. Głód wysysa siły witalne, pogrąża miasto i jego więźniów w zimno, wolny ruch i milczenie. Miasto przekształca się w świat pozagrobowy zamieszkały przez cienie: „Люди, как тени, медленно двигались по городу. Как во сне... В глубоком сне...”35. W wyniku długotrwałego głodu podmiotowość mieszkańców zostaje zachwiana, zatarta.

Nie mniej ważnym zagadnieniem są relacje między przestrzenią kulturową a pamięcią. Według Galiny Firsowej w powojennej topografii Petersburga nadal pozostały luki, które wymagają memorializacji: „В Ленинграде много памятников, но нет одного, который должен быть. О нем забыли. Это - памятник блокадной собаке" ${ }^{36}$. Tworzenie miejsc pamięci wyrażające się m.in. w stawianiu monumentów nie uwzględnia cierpienia zwierząt, choć były one nieodłączną częścią historii.

Podsumowując, w twórczości Swietłany Aleksijewicz dochodzi do konfrontacji zarówno różnych form pamięci (pamięć oficjalna - pamięć zmarginalizowanych jednostek), jak i rozmaitych rodzajów przestrzeni (swoja-obca; geograficzna-symboliczna; przedwojenna-wojenna-powojenna). W świadectwach o wojnie kategorie pamięci i przestrzeni są ze sobą ściśle powiązane, co oznacza, że nie tylko pamięć wskrzesza przeważnie nieistniejące już krajobrazy lub przywołując traumatyczne wydarzenia, implikuje przestrzenny porządek bohaterów w teraźniejszości, ale też zniekształcenie lub całkowite zniszczenie rodzimych miejsc może prowadzić do zaburzenia pamięci. W omawianych utworach przestrzeń najczęściej jest ukazana $\mathrm{w}$ trakcie przekształceń, podlega ona rozmaitym procesom m.in. dewastacji, homogenizacji, symbolizacji, oniryzacji. Krajobrazy

34 Tamże, s. 266.

35 Tamże, s. 268.

${ }^{36}$ Tamże, s. 269. 
wojenne zawarte $\mathrm{w}$ książkach Wojna nie ma $w$ sobie nic z kobiety i Ostatni świadkowie są doświadczane zmysłowo, a więc mamy tu do czynienia z przykładem geografii sensorycznej, w której istotną rolę odgrywają pejzaże dźwiękowe i wizualne. Poprzez swoje metody pracy zasadzające się na zgromadzeniu możliwie dużego materiału, opartego na setkach relacji świadków Aleksijewicz udaje się uchwycić powtarzalność niektórych motywów (spalona wieś, ziemia, rite de passage) i figur przestrzennych (dom, sierociniec, cmentarz, obóz), nie zatracając jednocześnie osobistego wydźwięku wspomnień swoich rozmówców.

\section{REFERENCES}

Aleksiyevich, Svetlana. Posledniye svideteli. Solo dlya detskogo golosa. Moskva: Vremya, 2017 [Алексиевич, Светлана. Последние свидетели. Соло для детского голоса. Москва: Время, 2017].

Aleksiyevich, Svetlana. Tsinkovyye mal'chiki. Moskva: Vremya, 2017 [Алексиевич, Светлана. Цинковые мальчики. Москва: Время, 2017].

Aleksiyevich, Svetlana. U voyny ne zhenskoye litso. Moskva: Vremya, 2007 [Алексиевич, Светлана. У войны не женское лицо. Москва: Время, 2007].

Bielska, Ewa. "Niewrażliwe państwo, wrażliwa literatura. Prace Swietłany Aleksijewicz jako egzemplifikacje traumy (nie)wypowiedzianej.” Kultura Wspótczesna 2018 no. 4.

Darska, Bernadetta. "Ludzie radzieccy. O tożsamości, nierównej walce z czasem, pamięci i zapomnieniu w reportażach Swietłany Aleksijewicz.” Tożsamość. Kultura. Nowoczesność. Vol. 2: Czas. Pamięć. Ed. Morzyńska-Wrzosek, Beata. Kurkiewicz, Marek. Szczukowski, Ireneusz. Bydgoszcz: Wydawnictwo Uniwersytetu Kazimierza Wielkiego, 2017.

Gorshenin, Aleksey. "O voyne - nevoyevavshiye.” Sibirskiye ogni 1985 no. 5 [Гopшенин, Алексей. “О войне - невоевавшие.” Сибирские огни 1985 nо. 5].

Gurska, Karolina. “KnigaS.Aleksiyevich 'Uvoynynezhenskoyelitso'kaktsiklicheskoye khudozhestvenno-dokumental'noyeyavleniye:strukturaipoetika."VestnikRUDN. Seriya: Literaturovedeniye. Zhurnalistika 2018 no. 2 <https://cyberleninka. $\mathrm{ru} /$ article/v/kniga-s-aleksievich-u-voyny-ne-zhenskoe-litso-kak-tsiklicheskoehudozhestvenno-dokumentalnoe-yavlenie-struktura-i-poetika> [Гурска, Каролина. “Книга С. Алексиевич 'У войны не женское лицо' как циклическое художественно-документальное явление: структура и поэтика.” Вестник РУДН. Серия: Литературоведение. Журналистика 2018 no. $2<\mathrm{https://}$ cyberleninka.ru/article/v/kniga-s-aleksievich-u-voyny-ne-zhenskoe-litso-kaktsiklicheskoe-hudozhestvenno-dokumentalnoe-yavlenie-struktura-i-poetika> ].

Hirsch, Marianne. "The Generation of Postmemory.” Poetics Today 2008 no. 29 $<$ https://urokiistorii.ru/sites/all/files/hirsch_generation_of_postmemory. pdf $>$.

Kępa, Sylwia. "Dlaczego wojna nie ma w sobie nic z kobiety?... Żołnierki II wojny światowej w reportażach Swietłany Aleksijewicz. Mapa mentalna.” Anna- 
les Universitatis Paedagogicae Cracoviensis. Studia Historicolitteraria 2015 no. 15 .

Kurzynoga, Monika. "Heterotopia domu dziecka, czyli o miejscu bez miejsca." Teraźniejszość - Człowiek - Edukacja 2012 no. 4(60) <http://terazniejszosc.dsw. edu.pl/fileadmin/user_upload/wydawnictwo/TCE/2012_6o_6.pdf>.

Lotman, Yuriy. "Pamyat'v kul'turologicheskom osveshchenii." 15 May $2019<\mathrm{http}$ // www.philology.ru/literature1/lotman-92f.htm> [Лотман, Юрий. "Память в культурологическом освещении.” 15.05.2019 <http://www.philology.ru/ literature1/lotman-92f.htm>].

Lugarić Vukas, Danijela. "Witnessing the unspeakable: on testimony and trauma in Svetlana Alexievich's The War's Unwomanly Face and Zinky Boys.” Kul'tura i tekst 2014 no. 3.

Novikau, Aliaksandr. "Women, wars and militarism in Svetlana Alexievich's documentary prose." Media, War \& Conflict 2017 no. 10 (3).

Rybicka, Elżbieta. “Miejsce, pamięć, literatura (w perspektywie geopoetyki).” Teksty Drugie 2008 no. 1-2.

Stelingowska, Barbara. “'Wojna nie ma w sobie nic z kobiety’ - wokół reportażu Swietłany Aleksijewicz.” Doctrina 2017 no. 14.

Stępniak, Anna. "Anioły czy wiedźmy? Kobiety w reportażu Swietłany Aleksijewicz Wojna nie ma w sobie nic z kobiety." Wiedźmy i anioty - postrzeganie kobiet $w$ dawnej $i$ wspótczesnej kulturze. Ed. Stanecka, Agnieszka. Dybała, Jolanta. Piotrków Trybunalski: Wydawnictwo UJK w Kielcach, 2017.

Szalewska, Katarzyna. Urbanalia. Miasto i jego teksty. Gdańsk: Słowo/ obraz terytoria, 2017.

Theiss, Wiesław. "Sieroctwo wojenne polskich dzieci (1939-1945). Zarys problematyki." Przegląd Pedagogiczny 2012 no. 1 <https://repozytorium.ukw.edu.pl/ handle/item/621>.

Volkova, Svetlana. "Ideyno-esteticheskaya funktsiya motiva 'posedelogo detstva' v knige S. Aleksiyevich 'Posledniye svideteli'.” Cuadernos de Rusística Española 2011 no. 7 <ttps://revistaseug.ugr.es/index.php/cre/article/view/103/102> [Волкова, Светлана. "Идейно-эстетическая функция мотива 'поседелого детства' в книге С. Алексиевич 'Последние свидетели'.” Cuadernos de Rusística Española 2011 no. 7 <ttps://revistaseug.ugr.es/index.php/cre/article/ view/103/102>].

Waligórska-Olejniczak, Beata. "O mitach i obrazach kobiecości w prozie Swietłany Aleksijewicz.” Porównania 2017 no. 1.

Zawadzki, Rachel. Violence and Emotion: Feminine Perspectives in the Works of Svetlana Alexievich, Luisa Valenzuela, Lydia Chukovskaya, and Claudia Hernández. Chapel Hill, 2018, <https://cdr.lib.unc.edu/concern/honors_theses/ st74cv233>.

Zywert, Aleksandra. "Śmierć i dziewczyna. 'Wojna nie ma w sobie nic z kobiety' Swietłany Aleksijewicz.” Kobiety i/a doświadczenie wojny. 1914-1945 i później. Ed. Grzywacz, Małgorzata. Okupnik, Małgorzata. Poznań: Wydawnictwo Naukowe Wydziału Nauk Społecznych UAM, 2015. 